\title{
Grundtvigs »Kirkens Gienmæle« - læst i et nutidigt perspektiv
}

\author{
Af Theodor Jørgensen
}

Lad mig til at begynde med præcisere min hensigt med at læse Grundtvigs kampskrift fra 1825 i et nutidigt perspektiv. »Kirkens Gienmæle« er det skrift, hvori Grundtvig for første gang programmæssigt, omend kortfattet, præsenterer sin »kirkelige anskuelse«. Han gør det i opgør med professor H.N. Clausen, som han opfatter som repræsentant for den rationalistiske protestantisme, som han som præst i denne kirke for kirkens skyld ønsker at distancere sig fra. Grundtvig taler ikke på egne, men på kirkens vegne; jvf. forordet: »For at betegne dette, for at minde om, at Striden fra min Side slet ikke er personlig, og ingenlunde blot videnskabelig, men saa reen kirkelig som mueligt, derfor kalder jeg dette Feidebrev Kirkens Gienmæle, indskydende dermed Sagen, fra den blotte Læse-Verden, for den almindelige Christenheds Domstol.« (Kirkens Gienmæle, US IV s. 397). I samme forord, skrevet på Irenæi dag, den 26. august 1825, fremhæver han også som betydningsfuld for dette hans opgør den inspiration, som han har modtaget fra Irenæus. Og som motto for hele skriftet sætter han et citat fra Confessio Augustana art. VII: Una sancta ecclesia perpetuo mansura sit. (Lad der bestandigt $\mathrm{i}$ fremtiden forblive én hellig kirke.) Alt dette gør det nærliggende at læse Grundtivgs kampskrift som et forsvar for en i traditionen og historien forankret kirkelighed. Det gør hans forhold til oldkirken interessant og hans høje vurdering af gudstjenesten og sakramenterne. Og set i det perspektiv kan Grundtvig opfattes som eksponent for den restaurationsbevægelse, der kendes i hele Europa i første halvdel af det 19. århundrede. Sådan har da også højkirkeligheden i Danmark altid gerne villet opfatte Grundtvig. Men denne opfattelse er for snæver og for ensidig. Og den er ufrugtbar. Den udnytter ikke de forståelsesmuligheder, som Grundtvig netop som et helt og fuldt 19. århundredes menneske giver os $\mathrm{i}$ hænde, når vi selv i det 20 . århundrede skal tage stilling til spørgsmål vedrørende forholdet mellem kristendom og nutid. Også dér, hvor Grundtvig gør op 
med sin samtid, gør han det som repræsentant for denne samtid. Med alle de ironiske bemærkninger, han har til overs for protestantismen, er han i den henseende selv en protestant. Som sådan formidler han arven fra oldkirken, den oldengelske kristne digtning, Luther og reformationen, og det er i dette nutidige perspektiv, at en læsning af »Kirkens Gienmæle« forekommer mig mest frugtbar.

Velvidende, hvor komplekst et problem nutiden (modernity) er, vil jeg alligevel fremdrage nogle også for Grundtvig centrale synspunkter som typiske for nutiden. Desforuden er jeg af den mening, at disse synspunkter samtidig også på godt og ondt er et resultat af kristendommens virkningshistorie.

1. Tro må være en erfaringssag, fordi den drejer sig om det enkelte menneskes frelse og dermed integritet. Derfor må det kristne trosindholds relevans kunne verificeres på det enkelte menneskes livserfaring. Grundtvig plejer her at tale om den venlige vekselvirkning mellem kristendom og menneskelighed. Men det forudsætter endvidere, at menneskets autonomi anerkendes. Kun hvad det enkelte menneske ud fra sin indre overbevisning kan anerkende som sandhed, kan det sige ja til. Her foreligger en arv fra reformationens afvisning af enhver menneskelig melleminstans mellem Gud og menneske. Men det betyder, at tro er en frihedssag, hvad Grundtvig ikke kan blive træt af at understrege. Kun i frihed kan det enkelte menneske sige ja til troens ubetingede engagement, der er ensbetydende med trosvished.

2. Tro må være en vishedssag. Den understregning af trosvishedens nødvendighed, som er karakteristisk for den af reformationen påvirkede teologi, hænger nøje sammen med erfaringens nødvendighed for troen. Den enkeltes erfaring er individuel og betinget. Den er endelig og kan som sådan være vilkårlig. Det er det relativitetsproblem, som ingen kan undslå sig, hvorfor visheden bliver så nødvendig for troen. I sin egen relative erfaring kan mennesket ikke finde grunden til vished. Den må søges udenfor. Her har den kollektive erfaring en betydning for den enkelte, sådan som den bliver til i historien, for den kollektive erfaring kan både virke korrigerende og bekræftende. Men den slår ikke til. Også den må have noget at forholde sig til, som begrunder den. Det er den klassiske teologiske problemstilling 
om forholdet mellem verbum externum og verbum internum, der ligger bag ved vishedsproblemet, eller også spørgsmålet om fundamentum fidei. Det fører over til det tredie synspunkt.

3. Troen må have kriterier for sin kristne identitet. Det har den altid haft brug for, fordi der altid $\mathrm{i}$ kristenheden har været diskussion om sand kristendom. Det vidner NT allerede om. Men i nutiden er identitetsproblemet blevet skærpet som en konsekvens af protestantismens understregning af troen som en erfarings- og en vishedssag. Den er for mig at se en afgørende forklaring på protestantismens fortsatte tilbøjelighed til at blive splittet op i et utal af denominationer, fordi den frister til at sætte egne trosmeninger absolut. Det absurde i denne udvikling er dens relativerende effekt, der gør den enkeltes kirkelige tilhørsforhold til et spørgsmål om individuel smag, hvor ikketeologiske faktorer i høj grad kan være udslagsgivende. Det er i denne sammenhæng, at spørgsmålet om den kristne kirkes kendetegn, nota ecclesiae, bliver så afgørende.

4. I besvarelsen af dette spørgsmål spiller teologien selvsagt en vigtig rolle. Men hvilken, og med hvilken autoritet? Den pluralitet af trosmeninger, som altid har karakteriseret kristendommen og må gøre det, gentager sig jo på det teologiske plan, selv om det teologiske arbejde sigter på at finde kriterier for kristen identitet for på den måde også at sætte grænser for pluraliteten. Hvis det er teologerne, der skal have det afgørende ord i spørgsmålet om, hvad der er sand kristendom, kommer man så ikke som lægmand fra asken i ilden? Og er den autoritetskrise, som i hvert fald universitetsteologien i dag gennemgående befinder sig i i forhold til kirken, ikke udtryk for, at forholdet mellem kirke og teologi er alt andet end klart?

Grundtvigs kampskrift »Kirkens Gienmæle« kan læses som en stillingtagen til disse fire synspunkter og bliver på den måde et bidrag til en almen debat, som vi befinder os midt $\mathrm{i}$ den dag $\mathrm{i}$ dag.

Men først vil det være på sin plads ganske kort at gøre rede for skriftets anledning og indhold. Anledningen var et digert værk af den unge teologiske professor H.N. Clausen med titlen »Catholicismens og Protestantismens Kirkeforfatning, Lære og Ritus «, der udkom i august 1825 . H.N. Clausen havde bl.a. studeret i Berlin, hvor han modtog stor inspiration fra Schleier- 
macher, hvis teologi da også har sat spor i dette værk, ikke mindst dets kirkebegreb. H.N. Clausen var professor i dogmatik og nytestamentlig eksegese ved Københavns Universitet, hvor hans indflydelse på de studerende var stor. Clausens bog satte Grundtvig i affekt. På mindre end en uge havde han forfattet sit modskrift, der udkom i begyndelsen af september. Hvad var det, der i den grad bragte Grundtvig i harnisk? I forordet sammenfatter han det som følger: »Nu har Professor i Theologien H.N. Clausen i fornævnte Bog paa det Udtrykkeligste og Stærkeste erklæret, at han ei vil taale nogen anden Kundskabs-Kilde eller Troes-Regel i den Christelige Kirke end Skriften, og ligesaa bestemt erklæret Skriften for usikker og selvmodsigende, hvoraf unægtelig følger, at han ei alene forkaster den Christelige Kirkes oprindelige Troes-Bekiendelse, men erklærer den giennem mange Aarhundreder bekiendte Christendom for aldeles ubekiendt og ukiendelig. Da han nu, desuagtet, ei blot vil hedde Christen, men giælde for en christelig Skrift-Fortolker, der kan lære Andre, hvad han, efter egen Bekiendelse, ikke selv veed: hvad der er ægte Christendom, saa maa han enten forsætlig ville bedrage sine Læsere og Tilhørere, eller han maa have været blind for de soleklareste Sandheder, og hvilken af Delene der er Tilfældet, maa han nu selv afgiøre, i det den klare unægtelige Sandhed foreholdes ham." (US IV s. 399f.).

Hvad der harmer Grundtvig, er Clausens efter hans mening uhistoriske opfattelse af kirken, hvor menigheden bliver gjort til et læseselskab, som må rette sig efter teologers indbyrdes forskellige og ofte modstridende skriftfortolkninger som kriterium for, hvad der er sand kristendom. Over for dette uhistoriske kirkesyn stiller han sit eget: »thi den Christelige Kirke er ingen tom eller omtvistelig Indbildning, det er en aabenbar Kiends-Gierning, et velbekiendt historisk Factum, som al Verdens Protest ei kan rokke et Haarsbredd, end sige tilintetgiøre.« (ibid. s. 398). I selve skriftet uddybes så dette kirkesyn, Grundtvigs såkaldte kirkelige anskuelse. Som historisk kendsgerning igennem alle århundreder siden Jesu tid har kirken kunnet kendes overalt på sin trosbekendelse og på nådemidlerne dåb og nadver. Grundtvig taler om »den urokkelige Kiends-Gierning, at der har været og er en Christenhed paa Jorden, kiendelig fra alt Andet paa sin mageløse Troes-Bekiendelse, hvormed den paa alle sine Tungemaal, 
under alle sine foranderlige Skikkelser, har forkyndt og forkynder Troen paa Jesum Christum, den Korsfæstede, igien Opstandne, som den sikkre, den eneste Saligheds Vei for Syndere, som en Vei, der, giennem Daaben og Nadveren, fører til Guds Rige og de Levendes Land.... Naade-Midlerne, med den dertil svarende Troes-Bekiendelse, som er det Eneste, alle Christne, $i$ alle Stillinger, $i$ alle Menigheder, til alle Tider have havt tilfælles, det, der baade har gjort Kirken kiendelig for Venner og Fiender, og forbundet Menigheden«. (ibid. s. 417).

De to kirkesyn, der her støder sammen, er på den ene side et kirkesyn, der er begrundet i et laerebegreb om kirken, - det er H.N. Clausens kirkesyn -, og på den anden side et kirkesyn, der påberåber sig historiens vidnesbyrd, dvs. den enkeltes konkrete historiske erfaring. Her står en læremæssig bestemmelse af kristendommen som religion over for en flerdimensional forståelse af kristendommen, svarende til professor Ninian Smarts religionsanalyse: »Religion is a six-dimensional organism, typically containing doctrines, myths, ethical teachings, rituals, and social institutions, and animated by religious experiences of various kinds." (The Religious Experience of Mankind, 1971, s. 31, her citeret efter S.W. Sykes, The Identity of Christianity, 1984, s. 28). Og stedet, hvor denne konkrete erfaring af kristendommen finder sted i dens flerdimensionalitet, er for Grundtvig gudstjenesten.

Jeg vil i det følgende ud fra de ovennæunte fire synspunkter gøre rede for og diskutere Grundtvigs overvejelser i »Kirkens Gienmæle«, men tillader mig også at inddrage senere udredninger hos Grundtvig om »den kirkelige anskuelse«.

\section{Tro må vaere en erfaringssag}

Det er selvfølgelig umuligt her at uddybe Grundtvigs erfaringsbegreb og sætte det i relation til de epistemologiske problemer, der generelt er knyttet til erfaringsbegrebet. Jeg vil kun pege på, at Grundtvigs understregning af troen som erfaring tjener en dobbelt hensigt: Troens indfældethed i overindividuelle livssammenhænge, her frem for alt historien, på den ene side, og troen som det enkelte menneskes mest fundamentale livsakt på den anden side. I erfaringen holdes det ydre og det indre, det kollektive og 
det individuelle, det åndelige og det legemlige, det himmelske og det jordiske sammen. Og Grundtvig lægger eftertrykket på de første begreber i de nævnte begrebspar, ikke for at fratage det andet begreb dets fulde vægt, så langt fra, men for at fremhæve det enkelte menneskelivs indfoeldethed eller - teologisk talt - dets skabthed. I »Kirkens Gienmæle« bruger Grundtvig erfaringsbegrebet polemisk imod H.N. Clausens konstruerende fornuft. Medens Clausen vil lægge et konstrueret lærebegreb om kirken til grund for sine udredninger, - kirke som samfund til fremme af almen religiøsitet -, som Grundtvig hånligt erklærer for at være et luftkastel af en kirke, påberåber Grundtvig sig erfaringens vidnesbyrd fra en kirke, der har eksisteret i mange hundrede år, og som i det grundlæggende altid har været enig om, hvad der kendetegnede den som kristelig. Erfaringens vidnesbyrd er historiens vidnesbyrd, der vokser $\mathrm{i}$ autoritet med årene. Og den er mest $\mathrm{i}$ overensstemmelse med den sande fornuft til forskel fra den falske, kødelige, idet »Sandhed altid sees at være en Dag ældre, fordi Løgn umuelig kan komme til Orde, før den har Noget at modsige, protestere imod: før den har noget Sandt at nægte.« (US IV, s. 417). Sandheden er altid forudgivet og er derfor kun tilgængelig for erfaring. Den må sanses, høres.

Grundtvigs erfaringsbegreb er begrundet $\mathrm{i}$ hans antropologi og teologi. I en afhandling fra 1817 skriver han: „Vi erfare giennem Hørelsens Sands ikke alene noget Legemligt - Lyden -, men også noget Aandeligt - Ordet -; thi Ordet er jo ikke andet end det Aandelige, der træder ud i Erfaringens Kreds og aabenbarer sig for Aander ... det er et unægteligt Vidnesbyrd om den inderlige Forbindelse mellem Aand og Legeme, der selv i Sandse-Verdenen aabenbarer sig: en urokkelig Mur mod al Idealisme, al Nægtelse af det Legemliges fornuftige Virkelighed « (US III, s. 413). Erfaring er sansende forståelse og forstående sansning, den er $\mathrm{i}$ sig selv en åndelig legemlig funktion og som sådan netop menneskelig erfaring. For mennesket selv er ifølge Grundtvig »et Guddommeligt Experiment, der viser, hvordan Aand og Støv kan giennemtrænge hinanden og forklares $\mathrm{i}$ en fælles guddommelig Bevidsthed « (US V, s. 408). Indledningen til Nordens Mythologi 1832). Beviset for denne guddommelige oprindelse er som bekendt frem for alt menneskets sprog, og vel at mærke ikke kun forstået som taleevne, men som det konkrete sprog, de levende 
ord, som mennesket har på tungen, og hvormed det kan udrette store ting. Og ordet selv er som hele mennesket denne enhed af st $\varnothing v$ og ånd, af lyd og mening. For Grundtvig er ord altid de talte ord. Nedskrevne ord er en - omend i visse sammenhænge nødvendig - deformation af sproget. For menneskeordet ef genlydsord af skaberordet, og det blev talt. Tilsvarende er organet for sproget, både for dets tale og dets forståelse, hjertet, ikke forstanden. Ånden taler eller synger med "støvhjertets tunger « (Lyksaligt det Folk, str. 1 GSV IV, s. 351). Og kun den hjertelige forståelse, dvs. den kærlige forståelse, er egentlig forståelse: »...og han har aldrig levet, som klog på det er blevet, han først ej havde kær « (Gyldenaaret, 1834, str. 41, US VII, s. 18). Det er i hjertet, at mennesket er mest sig selv, ikke i forstanden. Det er med hjertet, at mennesket ved om sin egen tilværelses fortabthed og længes efter og drømmer om en anden hel tilværelse. Og derfor er hjertet også sædet for troen på Guds frelse i Kristus samt for de to andre kristne livstegn, håbet og kærligheden. Kun med hjertet erfarer mennesket den venlige vekselvirkning mellem kristendom og menneskelighed.

Grundtvigs forsvar for menneskets frihed også i trosvalget og dermed dets autonomi er karakteristisk nok ikke et forsvar for fornuftens, men for hjertets autonomi. Af rationalismen var Grundtvig blevet tilstrækkeligt belært om, at fornuftens autonomi kunne udarte til et fornuftens formynderi i forhold til den enkelte, og det er også det samme formynderi, han så indædt bekæmper hos Clausen i »Kirkens Gienmæle «. Derimod er forsvaret for hjertets autonomi et forsvar for hvert enkelt menneskes umiddelbare forhold til Gud i en selvstændighed, der er fastholdt på skabthedens og dermed endelighedens vilkår. Dette må på ingen måde misforstås $\mathrm{i}$ retning af en antropologisk begrundelse af gudsforholdet. Det forholder sig snarere modsat. Hjertets autonomi forstået som dets umiddelbarhed til Gud modsvares af Guds suverænitet i sin tilgang til mennesket i kraft af sit ord, som er Kristus. Det er fordi Gud ikke lader sig binde af melleminstanser, at mennesket heller ikke er det: »Vi ere, vi bleve, / vi røres, vi leve / i Kristus, Guds levende Ord; / tag Ordet i Munden, / og elsk det fra Grunden! / Da hos dig i Navnet han bor.« (Trods længselens smerte str. 3, GSV V, s. 531). 


\section{Tro må vare en vishedssag}

Trosforholdets umiddelbarhed er dets vished. Liturgisk kommer det til udtryk i svaret: Amen! »Det er sandt. Sådan er det!« Det hørte budskab, det modtagne sakrament er hørt og modtaget som Kristus, Guds levende ord. Problemet er blot, at denne umiddelbarhed opstår i formidlethed. Budskabet møder mig som et andet menneskes ord, sakramentet rækkes mig af et andet menneske. Er visheden så ikke yderst skrøbelig? Nutidens bevidsthed om denne historiske formidlethed og dermed sammenhørende relativitet er vel nok en af de største udfordringer til troen som vished. Dog afspejler denne problemstilling sig allerede i reformationstidens kendte sola-formuleringer: Solus Christus, sola fide, sola scriptura, i deres indbyrdes sammenhæng, hvor de to første sola-formler står for troens umiddelbarhed, medens sola scriptura står for den formidlethed, som troen er henvist til. Men samtidig stilles det reformatoriske skriftprincip Skriftens formidling $\mathrm{i}$ modsætning til den formidling, der sker i kirkens overlevering, velvidende om denne modsætnings nødvendighed, hvis solus Christus og sola fide skal fastholdes. Men denne modsætning kan ikke længere fastholdes i den reformatoriske form på baggrund af den viden, som de eksegetiske videnskaber har forsynet os med. Gør man det alligevel, som Clausen gjorde det, fører det til konsekvenser, der i den grad vakte Grundtvigs harme. Grundtvig fastholder solus Christus og sola fide, men opgiver sola scriptura som det formidlende grundlag eller som trosregel for troen, og han $\mathrm{g} \emptyset \mathrm{r}$ det for trosvishedens skyld. For Grundtvig er Clausens synspunkt absurd, idet Clausen hævder: Til forskel fra den katolske kirke, som bygger på historiens vidnesbyrd, bygger den protestantiske kirke på skriften som eneste trosregel. Den er det normative udtryk for Kristi lære og ånd, og dermed grundlag for den kristne tro som det besjælende princip, som kirken skal formidle til alle jordiske forhold. I denne formidling skal kirken mest muligt overflødiggøre sig selv til fordel for Kristi lære og ånd. Ganske vist fastholder Clausen Skriftens sufficientia og dens perspicuitas, men samtidig fremdrager han alle de usikkerheder af forskellig art i teksterne, som skaber problemer ved deres fortolkning og fører til fortsatte stridigheder i den kristne verden. Det utålelige i Clausens syns- 
punkt er ifølge Grundtvig, at kristendom og bibel bliver til dæmoniske størrelser, på een gang sande og falske, og at det kristne lægfolk bliver udleveret til eksegeternes pavedømme, hvilket udelukker enhver trosvished. Er dette konsekvensen af reformatorernes forståelse af kirken og dens grundvold, har reformatorerne taget fejl. Og Grundtvig drager selv den konsekvens, at han opgiver Skriften som regula fidei.

Hvad sætter Grundtvig da i stedet? Han henviser til den apostolske trosbekendelse og nådemidlerne dåb og nadver, som må være kendetegnene på enhver kirke, der vil kalde sig kristen. Denne påstand fremfører Grundtvig »ikke blot som Theolog, ikke blot som kirkelig Boglærd, men fornemmelig som troende Medlem af den store almindelig-christelige Kirke, som. ved den apostolske Troes-Bekiendelse og Naademidlerne ei blot adskiller sig fra Jøder, Tyrker og Hedninger, men fornemmelig sikkrer sine troende Medlemmer Synds-Forladelse og Salighed i Jesu Christi Navn.« (US IV, s. 416).

For at forstå Grundtvig ret, må man her hæfte sig ved, at Grundtvig taler om Apostolicum i sammenhæng med dåb og nadver. Apostolicum karakteriseres sammesteds af ham som »det udelukkende Vilkaar for Indlemmelse i Samfundet«, hvis »saliggørende Kraft « svarer til nådemidlernes. Tydeligvis forstår Grundtvig altså ikke Apostolicum som lærebekendelse, i så fald ville man med rette kunne kritisere ham for en reduktionistisk tendens, når han som trosregel satte Apostolicum i stedet for Skriften, og eksegeternes pavedømme ville blive afløst af dogmatikernes, hvilket bestemt ikke ville give færre problemer. Hvad er så Grundtvigs opfattelse af den apostolske trosbekendelse?

Her mener jeg, at vi også skal tage det fingerpeg til efterretning, der ligger $\mathrm{i}$ det allerede citerede motto, hentet fra $\mathrm{CA}$ art. VII: Una sancta ecclesia perpetuo mansura sit. Fortsættelsen lyder: Est autem ecclesia congregatio sanctorum, in qua evangelium pure docetur et recte administrantur sacramenta. Ved nøjere eftersyn lader det sig faktisk gøre at læse de upolemiske afsnit af »Kirkens Gienmæle« som en udlægning af CA CII. For trosbekendelsens vedkommende kommer det så til at betyde, at den for Grundtvig indtager evangeliets plads. Trosbekendelsen er evangeliet i og med, at det tilsiges, forkyndes, og det sker frem for alt ved dåben. Apostolicum er pagtsordet fra Gud, igennem 
hvilket Gud slutter sin pagt med det enkelte menneske. Igennem dette pagtsord rækker Gud så at sige til den enkelte sin pagtshistorie frem, der spænder fra verdens skabelse frem til verdens genfødelse på den yderste dag og det evige liv, og det alt afgørende midtpunkt $\mathrm{i}$ denne pagtshistorie er det menneskevordne Guds Ord, Kristus, hans død og opstandelse, i hvem alt er sammenfattet. Trosbekendelsen har for Grundtvig sakramental karakter. Derfor kan han også karakterisere den som Kristi mundord, som i og med at vi tager det i munden og omfavner det med hjertet giver os fællesskab med ham: "Han hjertet tiltaler, / han hjertet hussvaler, / han svarer som Gud til sit navn; / når hjertet med varme / om Ordet slår arme, / vor frelser vi tager i favn.« (Trods længselens smerte str. 5. Jvf. Rom. 10,6ff. (GSV V, s. 532).

Denne opfattelse af trosbekendelsen står og falder ikke med, om den kan føres tilbage til Jesus selv, som Grundtvig en overgang mente det, eller ikke. Den er udelukkende betinget af den opstandnes levende tilstedeværelse i gudstjenestens sammenhæng ved dåb og nadver. Derfor kan Grundtvig til trosbekendelsen som Jesu mundord også føje dåbens og nadverens indstiftelsesord samt Fadervor og fredsønsket, der begge jo også indgår i dåbens sammenhæng. Den uundgåelige formidlethed, som den umiddelbare trosvished opstår af, er altså dåb og nadver samt trosbekendelse og Fadervor, sakramentalt forstået. Med andre ord: Kristus er i sit levende nærvær selv formidleren, og dermed er umiddelbarheden givet. Det viser sig også ved den måde, Grundtvig tilordner de kristne livsytringer til mundordene. Troen svarer til dåben, håbet til Fadervor og kærligheden til nadveren. Og disse tre livsytringer har så igen deres livstegn $\mathrm{i}$ henholdsvis bekendelsen, forkyndelsen og lovsangen. I disse livstegn er menneskets gudbilledlighed i genlydsordet igen kommet i sin sandhed. Kristenlivet er et Kristusliv i vækst, hvor troen gennem håbet vokser til fuldendelse $\mathrm{i}$ kærligheden og næres $\mathrm{i}$ gudstjenestens fællesskab med Kristus. Men væksten er Helligåndens gerning.

Regula fidei er således ifølge Grundtvig Kristus selv i sit levende nærvær i trosordet og sakramentsordene. Men det er unægtelig en trosregel, der er vanskelig at håndtere i spørgsmålet 
om kristen identitet, hvilket Grundtvig ingenlunde benægter. Det er snarere hans hensigt at lade denne vanskelighed bestå.

\section{Kriterier for kristen identitet}

I slutningen af »Kirkens Gienmæle « har Grundtvig en skarp diskussion med Clausen om den lovbefalede ed, som præster skulle aflægge $\mathrm{i}$ forbindelse med ordinationen. Grundtvigs og Clausens holdninger er illustrative for spørgsmålet om kriterierne for kristen identitet. Den centrale formulering i eden lyder: »Jeg lover: af alle kræfter ærlig at indprente mine tilhørere den himmelske lærdom, indeholdt $\mathrm{i}$ de profetiske og apostoliske skrifter og i de danske menigheders symboliske bøger«. Clausens indvending imod eden var, at man ved at underskrive den bandt sig til bogstaven, uden at der tydeligt var sagt noget om, i hvilken ånd bekendelserne skulle tolkes. Men edens ubestemte formuleringer gjorde, at enhver gejstlig alligevel uden betænkelighed kunne forpligte sig på den. Dog ville Clausen selv foretrække en ed, der sagde mere end den daværende og gjorde det mere tydeligt. For meningen kunne jo ikke være, at man skulle antage alt $\mathrm{i}$ de symbolske bøger for himmelsk lære. Clausen manglede en mere præcis angivelse af protestantismens og symbolernes ånd. Men den kunne man opnå ved, at man til eden knyttede en bekendelse på, at den hellige Skrift er den eneste trosnorm, at dette protestantismens princip er det sande kirkelige princip, og at den protestantiske kirke er dette princip tro, når den forkaster sætningen om retfærdiggørelse ved gerninger og læren om syv sakramenter, samt en forpligtelse til at lære efter denne tro. Dermed ville man antyde det faststående og det bevægelige i protestantismens væsen. Man ville fastslå de kristelige hovedsætninger, som måtte anses for resultater af det protestantiske fortolkningsprincip og dermed som aksiomer for protestantisk kristendom.

Det er ganske klart, at Clausen placerer sig i en tradition i protestantisk teologi, der vil finde kriterier for kristen identitet og inden for den for den protestantiske identitet ud fra en væsensbestemmelse af kristendommen eller ud fra en bestemmelse af dens grundanskuelse, dens princip, dens ånd, eller hvad 
man nu anvender for begreber. De karakteristiske hovedsætninger eller aksiomer må ikke opfattes som mindstemål af fundamentalartikler $\mathrm{i}$ et kristent læresystem, men netop som kriterier for kristen og protestantisk identitet, der tjener som fortolkningsregler. Her er kristendommen forstået som en trosmåde, en religiøs grundanskuelse, der i kirken er blevet samfundsskabende og igennem sit livssyn gennemsyrer det øvrige samfund.

Det siger sig selv, at Grundtvig må reagere skarpt, for der er en væsentlig forskel imellem kristendommen forstået som grundanskuelse og kristendom forstået som kirke i betydning af Kristi levende nærvær $\mathrm{i}$ trosordet og sakramenterne midt $\mathrm{i}$ hans bekendende menighed. Grundtvigs svar til Clausen er i sin hæftighed ikke videre klart, men et par enkelte punkter vil jeg drage frem som relevante. (jvf. til det følgende US IV, s. 422ff.). Grundtvig hæfter sig for det første ved, at der i præsteeden endvidere står, "at jeg ikke alene selv vil flye og skye den mod Guds Ord stridende Lærdom, men også af al Magt bestride den.« Vi har set, hvad betegnelsen »Guds ord « står for hos Grundtvig, nemlig Kristus selv. Dette uforanderlige ord er præsten som menighedens tjener sat til at forkynde til oplysning og opbyggelse. Og i den forstand er bogstaven i de profetiske og de apostolske skrifter samt de symbolske bøger bindende, at præsten i eden lover »at forkynde Alt, hvad der i benævnte Skrifter udgiver sig for himmelsk, guddommelig Lardom, som en saadan...«. Guds ord skal forkyndes som Guds ord. For skriftprincippets vedkommende gør Grundtvig gældende, at Skriften selv er misforstået, hvis den opfattes som trosregel. Det kan i Skriften egentlig kun hævdes om Mose lov. Endvidere må det at gøre skriftprincippet gældende »som det eneste rette i den sande Kirke, altsaa at Bogstavet var Alt, Aanden og det levende Ord i Bekiendelsen Intet«, afvises af enhver kristen som »Bog-Afguderie «. Endelig anser Grundtvig det for »Daarekiste-Snak « fra Clausens side, når denne mener, at man er protestantismens skriftprincip tro, når blot man forkaster læren om gerningsretfærdighed og læren om de syv sakramenter.

Det fremgår tydeligt af Grundtvigs argumentation, at han ikke fatter Clausens synspunkt så at sige indefra, hvad man heller ikke kan laste ham for. Grundtvig ser ikke, at Clausen ud fra sine forudsætninger er konsekvent nok. Gør man kristendommen 
til en grundanskuelse, udtrykt i Jesu lære og ånd, så er det konsekvent, at man går tilbage til de kilder, som vidner om dens oprindelse, og benytter dem hele tiden som reference $i$ en nybesindelse på den kristne grundanskuelse eller på kristendommens væsen. Samtidig må man selvfølgelig tage de historiske videnskabers nyeste erkendelser til efterretning i omgangen med Skriften som kilde. Det er der ikke noget selvmodsigende i. Den historiske kritik tjener tværtimod til en endnu præcisere bestemmelse af det centrale i kristendommen. Men hele denne tænkemåde er så væsensforskellig fra Grundtvigs måde at tænke på, at de må komme i konflikt.

Grundtvigs egen position har jeg allerede præciseret $\mathrm{i}$ det foregående: Regula fidei eller kriteriet for kristen identitet er Kristus selv i sit nærvær i trosbekendelsen, forstået som pagtsord og trosord, og i sakramenterne. Med andre ord: Kriteriet er den kristne gudstjeneste. Det er et kriterium af en helt anden art end Clausens. Medens Clausens er et teologisk læremæssigt og i den forstand intellektuelt kriterium, er Grundtvigs kriterium udledt af den historiske erfaring, den enkeltes og kristenhedens. Det er derfor, han i diskussionen med Clausen så energisk fremhæver, at »Den christne Kirke er en aabenbar Kiends-Gierning, et velbekiendt historisk Factum«, der aldrig har været i tvivl om, hvad der konstituerede den som kristen kirke, hvilket den har udtrykt og udtrykker ved at gøre den apostolske trosbekendelse til dåbsvilkår og ved at henvise til dåb og nadver som kilder for det kristne liv. Men er det så ikke sensus ecclesiae forstået som consensus ecclesiae, der bliver det overordnede kriterium, som så må karakteriseres som katolicerende? Det ville Grundtvig afvise på det bestemteste. Henvisningen til den ene kristne kirke som historisk kendsgerning er for ham ensbetydende med bekendelsen til Kristus som kirkens eneste herre. Og gentagne gange understreger han over for Clausen, at det netop var reformatorernes hensigt at forsvare denne ene sande kirke fra dens begyndelse over for Romerkirkens afvigelser. Han kan således sige: »Erfaringens historiske Vidnesbyrd er det Eneste, der ærer Christus, Bibelen og Luther.« (US IV, s. 405).Erfaringens historiske vidnesbyrd er for Grundtvig identisk med gudstjenestens erfaring $i$ et diakront og synkront perspektiv. 
Dette er et så vigtigt aspekt $\mathrm{i}$ en nutidig læsning af »Kirkens Gienmæle«, at jeg gerne vil uddybe det mere. Og jeg vil gøre det ved hjælp af et synspunkt, hentet fra Stephen W. Sykes meget læseværdige bog »The Identity of Christianity« (1984), der for mig at se i sin grundholdning er dybt beslægtet med Grundtvigs »Kirkelige anskuelse «. Sykes fastslår, at uenighed er umulig at undgå $\mathrm{i}$ formidlingen af det kristne trosindhold, da den er et vilkår for denne formidling. Den opstår jo netop i bestræbelsen for at fastholde kristen identitet. Det afgørende spørgsmål er, hvordan man omgås med denne uenighed, og ikke mindst hvilken rolle teologerne her spiller. Det er også et grundspørgsmål i »Kirkens Gienmæle«. Sykes understreger, at en enhed i synkron og diakron forstand må kunne fastholdes i kristendommen, som også bliver tydelig i det svar, som kristne giver på denne enhed, uanset at svarene i deres formuleringer kan være ret forskellige. I modsat fald splittes kristendommen i et antal indbyrdes disparate grupperinger. Og Sykes argument for, at denne enhed forefindes, er, at netop uenigheden $\mathrm{i}$ de indbyrdes stridende teologier ville blive uforståelig, hvis ikke de blev set i relation til denne enhed, der af gode grunde netop ikke kan være en læreenhed. Enheden er personen Jesus i hans særlige forhold til Gud. Sykes opstiller tre punkter som væsentlige for denne forudsatte enhed i uenigheden:

1. I Jesus, i hans liv og gerning, må Gud have skabt noget egentligt nyt, grundlaget for en ny eksistens, den kristne.

2. Den Gud, der har skabt dette nye i Jesus, er også skabelsens Gud, der i begyndelsen skabte himmel og jord og fortsat opretholder sin skabning.

3. Som Gud er begyndelsens Gud, er han også fuldendelsens Gud. I Jesu død og opstandelse forkyndes det, at Gud er herre over døden, også den enkeltes, idet fuldendelsen er forudgrebet (prefigured) i Jesu opstandelse. (Jvf. Sykes s. 257 og hele kapitlet 10, s. 239-261.)

Det vigtige perspektiv i denne måde at formulere en kristen enhed på er, at Gud og verden holdes sammen i Jesus, og dermed holdes også det enkelte menneskes og menneskeslægtens eksistens sammen med Gud i Jesus. Det er den diakrone og den synkrone enhed, som Sykes taler om, der kun giver mening, hvis hele historien tænkes med som Guds historie med verden. Det 
er præcist det, Grundtvig mener med erfaringens historiske vidnesbyrd. Her sammenholdes de to dimensioner, som i det dogmatiske sprog udtrykkes ved fides quae creditur og fides qua creditur, og som Sykes bestemmer som »outward tradition « og »inward tradition « eller »the external $\ll$ og »the internal dimension of Christian faith«. For Grundtvig kommer »the external dimension « primært til udtryk i trosbekendelsen og sakramenterne, men også i Skriftens vidnesbyrd om kirkens herre, der levende er til stede i gudstjenestens fællesskab. Og »the internal dimension « er for Grundtvig det nye Kristusliv, der kommer til udtryk i livsytringerne tro, håb og kærlighed. Sykes har analoge formuleringer. Og Sykes konklusion kunne også have været Grundtvigs i synet på kristen identitet: "It is in the process of interaction between this inward element and the external forms of Christianity that the identity of Christianity consists « (op. cit. p. 261). For denne proces er kun tilgængelig igennem erfaringens historiske vidnesbyrd. Aflæsbar er den for Grundtvig især i menighedens livstegn i tidens løb, i gudstjenestens bekendelse, forkyndelse og lovsang. Og for at gøre denne diakrone erfaring synkron i gudstjenestens sammenhæng, gendigtede han gammeltestamentlige og nytestamentlige salmer og hymner, samt græske, latinske, oldengelske, engelske og tyske salmer og digte til danske salmer, svarende til, at han forstod kirkens historie som en række kristne folkemenigheders historie. I sin salmedigtning omsatte Grundtvig den kirkelige anskuelses forståelse af kristen identitet $\mathrm{i}$ liturgisk praksis.

\section{Kirke og teologi}

Levnes der teologien nogen plads i den kirkelige anskuelse? Er den nødvendig for kirken? Nu er den kirkelige anskuelse jo selv en form for teologi ved at være en eftertænkning af, hvad der udgør kirkens sande enhed og identitet. Den er en gudstjenestens teologi. Men spørgsmålet er alligevel berettiget. For hvilken funktion levnes der teologien? Den har ingen konstitutiv funktion, da trosbekendelsen ikke forstås som lærebekendelse og Skriften ikke som trosgrundlag. Da er dogmatikkens og eksegesens betydning vitterlig relativeret. »Ingen Menighed kan kiende, 
samle og bekiende Alt i Skriften, og Ingen af os kan døe i Jesu Christi Navn på vor egen Skrift-Fortolkning, eller paa noget Menneskes Ord, der ei have Guds øiensynlige Vidnesbyrd«, som »den oprindelige Bekiendelse (havde det) for Kirke-Fædrene.« (US IV, s. 418f.). Det er ikke teologien, der magter at gøre Kristus lyslevende for menigheden ved at oversætte og fortolke fortidige tekster ind i nutiden. Det magter kun »Guds øjensynlige vidnesbyrd«, Kristus som trosordet. Grundtvig vender så at sige hermeneutikken på hovedet. Det er Kristus, der i sit levende nærvær $\mathrm{i}$ menigheden ved Helligånden overvinder den Lessingske grøft mellem fortid og nutid ved selv at nutidiggøre sin egen jordiske fortid, som den er bevidnet i Skriften. Derfor kan Grundtvig i striden med rationalismens og Clausens teologi opfordre alle dem, som »i Sandhed vil være Christne«, til, »at vi, saa at sige, trække os tilbage til Choret, række hinanden, og alle de i Herren hensovne Christne, Haand over Daaben, og Mund for Alteret, i det ene Brød og den ene Kalk, lade, som Brødre al Kiv om det Tvivlsomme fare ... Ja, Christne! hvor I bygge, det er Tid, at vi igien forenes om det Christelige, som Laeg og Laerd, og som (NB!) de i Tanke-Gang forskielligste christelige Lærere, som en Justinus Martyr og Irenceus, Ansgar og Luther, Reinhard og Balle havde tilfælles, og som da unægtelig er det GrundChristelige, forene os derom, taale hos hverandre (NB!) al dermed forenelig theologisk Forskjellighed...« (ibid.). I forhold til det, som kirkens kor symboliserer, det grundkristelige, kommer teologien i anden række. Det er dens begrænsning men også dens frihed, der tillader forskellighed. Ikke blot kan teologien være forskellig, den skal oven i købet være det i den rolle, som den har på anden række. Det præciserer Grundtvig ved at skelne mellem kirke og skole eller kirkeskole. Kirken er bundet af »Guds øjensynlige vidnesbyrd«: »..ingen Fortolknings-Regel, uden den, at Skriften skal forstaaes efter Troes-Bekiendelsen, og ikke kan forstaaes uden af Troende med den Hellig-Aand, ingen Fortolknings-Regel uden denne, har den apostolske Kirkes og Historiens guddommelige og menneskelige Vidnesbyrd.« (ibid., s. 419). Kirken er forpligtet på denne fortolkningsregel. Den er den hermeneutiske konsekvens af forpligtetheden på den levende Kristus. Grundtvig kan andetsteds udtrykke det på den måde, at Skriften ligger på alteret og skal læses og tolkes tilsvarende. 
Men så fortsætter Grundtvig i den lige citerede sammenhæng, at kirken skal »lade Skolen i Øvrigt være fri, lade sine Theologer og Skriftkloge overlægge, og, vil de endelig, da kives med hinanden, naar de kun indrømme, at den hellige Skrift er oplysende og opbyggelig for alle Christne, efter Troens og Viisdommens Maal, som Herren giver, og naar de kun ikke prøver paa at sætte Spliid mellem Skriften og Kirkens Grund-Bekiendelse, hvorved de naturligvis udelukke sig selv af Kirken, og af KirkeSkolen.« (ibid.). Teologien er for så vidt undergivet den samme forpligtelse som kirken, og det vil sige det samme kriterium på kristen identitet, hvis den vil kalde sig kristen, men inden for denne forpligtethed har den ikke blot en ret, men også en pligt til forskellighed og foranderlighed. Hvis ikke teologien vil underkaste sig denne forpligtelse, kan den efter Grundtvigs mening for den sags skyld godt fortsætte sit arbejde ved universitetet og kalde sig, hvad den vil, protestantisk, rationalistisk, ja, selv luthersk, men kristen er den ikke, og inden for kirke-skolen har den ikke plads.

Men hvori består så helt præcist ifølge Grundtvig teologiens funktion i forhold til kirken? Det udtrykker Grundtvig som nævnt med begrebet kirke-skole. Skolen har altid oplysende funktion, hvad enten den er kirke-skole eller folke-skole. Og oplysning er for Grundtvig ensbetydende med livsoplysning. Kirke-skolen kan ikke formidle det nye liv i Kristus, det kan kun Kristus selv i kirken ved dåb og nadver. Men kirke-skolen eller teologien kan oplyse det nye Kristusliv for menigheden. Og i den forbindelse kan Grundtvig så tilskrive Skriften al den betydning, som han fraskrev den som fundament for troen og for kirken.

Skriften, og her især Ny Testamente, som Grundtvig ynder at kalde »Apostel-Skriften«, »bidrager saa usigelig meget til DaabsPagtens Oplysning og rette kristelige Forklaring, at vi dertil nu maa finde den uundværlig « (US IX, s. 387). Ny Testamente er det apostolske trosvidnesbyrd. Den er udtryk for det svar, som apostlene og den ældste menighed gav på Kristus som Guds levende Ord, og rummer derfor nødvendigvis den forskellighed, der hører livet til, også det nye liv i Kristus. Og den forskellighed er ligefrem en fordel, når $\mathrm{Ny}$ Testamente skal bidrage til dåbspagtens oplysning og forklaring. Som oplysningsbog har Skriften også en kritisk autoritativ funktion. Den er virket af 
Ånden, selvfølgelig ikke som bogstav-skrift, men hvad indholdet angår. Derfor kan den være prøvesten for menigheden, når det gælder om at skelne "Christi Aands Indskydelser fra alle Andre«. Men Grundtvig understreger, at Ånden har beredt sig Skriften som denne prøvesten »til sit eget fri Brug, ... hvori hans Redskaber (dvs. kirkeskolens lærere eller teologerne), ligesom Herren selv i sin Opvæxt, kan finde Stadfrestelse paa Aandens Indskydelser.« Til Åndens frie brug af Skriften som prøvesten svarer teologiens frihed i kirkeskolen. For det er på ingen måde Skriften, der ved Åndens frie brug af den bliver gjort til levende ord på vore tunger, men det til grund for Skriften liggende »MundsOrd«. Skriften kan som oplysningsbog aldrig have andet end henvisningskarakter i forhold til Kristus selv som Guds levende ord. Hvad teologen er forpligtet på i forhold til Skriften er dens selvforståelse som vidnesbyrd, som henvisning, ikke andet. I den henseende må teologen ikke være klogere end Skriften, »mens han i Menigheden vedbliver at være lige saa frit stillet til Skriften, dens Brug og Fortolkning, som Aanden stiller sig, og som Menigheden er stillet til Aanden, Præsten og Profeten « (jvf. til hele sammenhængen US IV, 732f.). For her skal teologen oplyse og klarlægge den kristne eksistens i dag, som den er skabt ved Kristi levende nærvær i ord og sakramenter. Og den kristne eksistens i dag må nødvendigvis forme sig forskelligt $\mathrm{i}$ adskillige henseender fra den kristne eksistens i de første kristne menigheder, ikke mindst når erfaringens historiske vidnesbyrd inddrages.

Med andre ord forsvarer Grundtvig en forståelse af teologien som kontekstuel teologi, der hænger nøje sammen med hans gudstjeneste- og kirkesyn og hans historiesyn. Og i en kontekstuel teologi må der nødvendigvis være forskelligheder, modsætninger og oven i købet strid. Hvis ikke det var tilfældet, ville teologien ikke leve op til de krav om livsoplysning, som kirkeskolen stiller. Medens kirken må stå fast på sin grundvold, Kristus, må skolen gå med livet, fordi livet ikke står stille, dog altid i forpligtethed på grundvolden. (jvf. GSV III, 150).

Hvad er så teologiens særlige opgave set i relation til spørgsmålet om kristen identitet? Ifølge Grundtvig i hvert fald ikke den at gøre sig til pave i kirken ved at tiltage sig myndighed til at fastslå, hvad der er sand kristendom. Kristen identitet står 
Kristus inde for, fordi han er den selv. Den kan kun erfares og må til stadighed erfares i mødet med Kristi nærvær i ordet og sakramenterne. Og denne gudstjenestlige erfaring er andet og mere end en intellektuel forklaring. Men den kan underkastes en intellektuel forklaring, og den kan og skal teologien tage sig af, for kristen tro er ikke obskur. I Kristus er jo sandheden blevet åbenbar. Et af de skriftsteder, som Grundtvig gang på gang i sin prosa og poesi direkte og indirekte alluderer til, er Joh. 1,4: I ham var liv, og livet var menneskers lys. Det skriftsted ligger bag den betegnelse, som Grundtvig ynder at bruge om Kristus: Lyslevende. Og det er hans teologiske begrundelse for skolen som livsoplysning. Teologiens funktion i forhold til kristen identitet er til hver en tid og i tidens forskellige sammenhænge at kaste lys over det liv, som er givet med Kristus, og gøre det $\mathrm{i}$ stadig vekselvirkning og samtale med, hvad der iøvrigt rører sig i tiden af spørgsmål og overvejelser vedrørende menneskelivet. Teologiens opgave er at udfolde den livsanskuelse og livspraksis, der følger af Kristuslivet i tro, håb og kærlighed. At den opgave kun kan løses $\mathrm{i}$ frihed og nødvendigvis må rumme forskelligheder, der også kan stå i spænding til hinanden, siger sig selv.

\section{Konklusion}

Hvilken relevans kan Grundtvigs »kirkelige anskuelse « have for os i dag? Den skærper i hvert fald vores problembevidsthed om kristendommens situation i de samfund i dag, der for alvor er præget af nutiden på den måde, at den enkeltes livsanskuelse eller religion er blevet et spørgsmål om den enkeltes valg, m.a.o. kristendommens situation i et pluralistisk samfund. Valg sker altid på grundlag af en overvejelse, en refleksion, som - talt med Grundtvig - finder sted i skolen. Men grundlæggende for Grundtvigs »kirkelige anskuelse« er jo netop, at man ikke kan undervise og oplyse til kristen tro. Den må erfares og skænkes i gudstjenestens sammenhæng. Man kan i skolen berede vejen for troserfaringen ved at klarlægge forhold i menneskelivet, der åbner menneskers forståelse for kristendommen. Det lagde Grundtvig selv megen vægt på, når han fremhævede nødvendig- 
heden af at være klog på menneskelivet, inden man kunne blive klog på kristenlivet. Men formidle det sidste kan man ikke.

Hvad stiller vi så op i dag, hvor den kristne gudstjeneste føles fremmed af mange og derfor tilsvarende fejres af få? Og hvor den enkelte vil have den kristne livsanskuelse udfoldet så at sige i konkurrence med andre, før han eller hun træffer sit trosvalg? For mig at se aftegner der sig i nutidens teologi to veje som typiske $\mathrm{i}$ arbejdet med at tage denne udfordring op. Den ene vej er at gøre kristendommens liturgiske og sakramentale erfaring begribelig for dels at motivere mennesker til selv at gøre den, dels at hjælpe kirken til at fejre sin gudstjeneste bedre i overensstemmelse med dens indhold. Repræsentativ for en sådan »gudstjenestens teologi« er for mig at se Geoffrey Wainrights »Doxology« (1980) og også de overvejelser, som S.W. Sykes har gjort $\mathrm{i}$ allerede nævnte bog, som med en indre nødvendighed munder ud i et afsluttende kapitel om »Worship, Commitment and Identity«. Denne vej er for mig at se en videreførelse af, hvad Grundtvig forsvarede med sin »kirkelige anskuelse«. Dens vanskelighed består i gudstjenestens krise i dag, som teologien ikke kan løse. Den kan kun kirken selv løse, fordi den hænger sammen med kirkens liv.

Den anden vej er bevidst at skelne imellem kirken som trossamfund og kristendommen som livsanskuelse ud fra en erkendelse af, at kristendommen som livsanskuelse også i dag har en direkte og indirekte indflydelse $\mathrm{i}$ samfundet, der når betydeligt længere end kirkens, og at det er muligt at argumentere for den på en måde, så der skabes et overbevisende grundlag for et trosvalg. Her har man fuldt accepteret, at forholdet mellem tro og livsanskuelse vendes om på modernitetens vilkår. Det betyder på ingen måde, at man ikke vil tænke den liturgiske og den sakramentale dimension med, men man tænker den med som en del af anskuelsen. Repræsentativ for denne vej forekommer W. Pannenbergs teologi mig at være, som den f. eks. kommer til udtryk i hans nylig udkomne »Systematische Theologie « Bd. 1 og 2 (1988 og 1991). Men Pannenberg opfylder klart den betingelse, som Grundtvig stillede for en kristen teologi, at den skal være forpligtet på den kristne åbenbaring.

Jeg for min part vælger den første vej, men kan ikke nægte, at den anden vej rummer indsigter og muligheder, som ikke 
mindst $\mathrm{i}$ apologetiske sammenhænge viser dens berettigelse. $\mathrm{Og}$ de to veje repræsenterer den forskellighed, som ikke blot er tilladelig, men nødvendig i teologien. 